\title{
The role of gender in further training in Spain: are employers making a difference?
}

Rosa Aisa

University of Zaragoza, Economic Analysis Department

raisa@unizar.es

Tel : +34976762789; Fax : +34976 761996

María A. González-ÁLvarez

University of Zaragoza, Economic Analysis Department and Economic Strategies \& Initiatives (ESI, SL.)

mara.gonzalez@esisl.com

Gemma Larramona

University of Zaragoza, Economic Analysis Department

gemmalar@unizar.es

\section{Abstract}

This paper investigates whether gender differentials in continuing training exist, in the case of Spain. Although we find no gender gap in the probability of overall training participation, gender discrimination emerges when the employer is financing the training. Evidence indicates that a greater motivation on the part of individuals to enhance their career prospects leads to a positive training gap for women in public-financed and self-financed training, whereas discrimination may account for a negative gap in firm-financed training. Furthermore, men who attend firm-financed training courses report higher average increases in wages, compared to women participating in the same type of training.

JEL codes: J16, J71, M53

Keywords: Continuing training, gender differences

Acknowledgements: The authors are grateful for the financial support received from the Public Employment Service of Aragón (INAEM). 


\section{Introduction.}

One of the reasons provided in explaining gender discrimination in the labor market is the existence of a gender gap in access to continuing training ${ }^{1}$. However, there is a lack of consensus in the economic literature as to whether men or women train more. While some studies show that women receive less continuing training than men, some others find no significant differences in the rates of continuing training by gender, or even find a positive training gap for women. Focusing on recent evidence, Dieckhoff and Steiber (2011) find that male employees are more likely to train than their female colleagues, using data for 23 European countries and controlling for worker, firm and job characteristics. However, Jones et al. (2008), report that women in the UK are more likely to receive continuing training than men (and they point to the importance of distinguishing between different types of continuing training). In particular, these authors discriminate amongst on-the-job training, employer-supported off-the-job training, and off-the-job training without employer support. They find that women are more likely to receive training in any and all of the categories mentioned, claiming that characteristics such as sector, occupation, and industry explain this gap, with the exception of the employer-funded off-the-job training category. Previous work by Simpson and Stroh (2002) also reported a higher incidence of females taking continuing training in the US, pointing out that the 1990s introduction of computer technologies in female-dominated occupations could explain the increasing rates of training among women. However, Evertsson (2004), who exclusively analyzes on-the-job training, using Swedish data from the mid-1990s, shows that women are less likely than men to take part in this training category. Using Swiss Labour force Survey data from 2006 and 2009, Backes-Gellner et al. (2011) find that being female has a negative effect on the probability of participating in employer-provided training, i.e. training that employers finance, that occurs during working hours, or both.

In this paper, we begin by building a theoretical model that brings together some of the main features of theories explaining gender differences in continuing training participation (Dieckhoff and Steiber, 2011): Human Capital Theory, Gender Roles Explanation, Discrimination Theory, and Gender Occupational Segregation. In this model, an employee (male or female) decides endogenously whether to participate in training. We assume that the employee takes into account both economic returns (e.g. if the training increases wages), and non-economic returns (e.g. if the training increases job satisfaction, or the self-fulfillment derived from the learning process itself). The optimal decision may be restrained by the training supply, depending on the source of funding: employer-financed training, public-financed training, or self-financed training. This framework

\footnotetext{
${ }^{1}$ See for instance, Tomaskovic-Devey and Skagg (2002), Evertsson (2004) and Havet and Sofer (2008)
} 
allows us to detect different gender patterns with respect to training, attributable to the adjustment between the demand and the supply. In this context, the source of funding emerges as a relevant factor in determining the employee's rate of participation in training.

Second, we investigate whether gender differentials in continuing training exist in Spain, using survey data containing detailed information on the incidence of training among Spanish workers in 2007. We consider continuous training as any type of training aimed at improving knowledge or skills in the workplace; in other words, professionally-oriented courses. We distinguish between worker and employer rationales regarding training, since we can differentiate whether the training is financed by the employer, the worker, or a public institution. The public sector as an alternative source of funding is particularly important in the Spanish case, since public training programs are widespread; in fact, Spain is above the European mean in the percentage of workers participating in continuing training, but below that mean regarding employer-financed training (Continuing Vocational Training Survey, 2005). Thus, in Spain, active labor market policies offer expanded training opportunities to many workers, improving their access through offthe-job training.

Knowing whether the training was financed by the employer, and whether it took place during or outside contracted working hours, allows us, first, to determine what factors explain the decision to participate and, second, to detect whether gender discrimination is present in employer-provided training - and if this is the case, whether publicly-financed training compensates for gender discrimination. In our analysis we go one step further, since we are interested not only in training participation rates, but also in the returns from the training. We investigate whether there exist any gender differences in the returns from, and motivations to participate in, different types of training in the Spanish labor market.

The rest of the paper is organized as follows. Section 2 presents the theoretical model. Section 3 introduces our data, describes the empirical strategy, and presents the estimation results. Finally, section 4 discusses our main results.

\section{Theoretical model}

Let us consider an employee (male or female) who derives utility from goods consumption, $c$, and training participation. Training is classified in three categories, depending on the source of funding: participation in training financed by the firm $\left(t_{f}\right)$, participation in training financed by the 
public sector $\left(t_{p}\right)$ and participation in training fully financed by the employee $\left(t_{s}\right)$. We assume the following individual utility function:

$$
U^{i}=V(c)+Z^{i}\left(t_{f}, t_{p}, t_{s}\right)-\Phi^{i}\left(t_{f}, t_{p}, t_{s}\right) \quad i=\text { male, female }
$$

where $c$ is the level of consumption goods and $Z^{i}$ ( ) denotes the utility gains derived from training. Although most previous literature focuses on wage returns to training (Dearden et al. 2006; Leuven and Oosterbeek, 2008; Görlitz, 2011), certain studies also highlight the importance of the nonmonetary returns to training, such as job satisfaction or personal satisfaction (Siebern-Thomas, 2005). In the final term of equation (1), $\Phi^{i}$ ( ) denotes the effort associated with training, that could be related, for example, to the opportunity cost of giving up alternative activities (such as caring for children, or other housework and leisure activities).

The Gender Role Theory establishes that those individuals living in a traditional environment will accept men acting as the main breadwinners and women as the main homemakers (England, 2005) and, therefore, the utility costs derived from training will be greater for women than for men. Our model allows us to incorporate this aspect of the gender role theory easily by assuming that $\Phi^{\text {male }}()<\Phi^{\text {female }}()$. This perspective focuses on cultural and social norms rather than a purely rational investment choice. This is also related to Human Capital Theory that, concentrated on the incentives to invest in training, establishes that care responsibilities lead to shorter and more discontinuous working lives among women and, therefore, to shorter periods in which the investment in training can be recovered (Becker, 1985).

Focusing now on the budget constraint, we consider that each training category leads to a different wage return. Previous evidence supports this assumption. Using data from France, Havet and Lacroix (2010) conclude that returns to training are different in terms of gender. From the Swedish Survey of Living Conditions, Evertsson (2004) finds that women are not rewarded for their skills acquired through on-the-job training to the same extent as are men. Also, we assume that each individual is endowed with 1 unit of time that can be allocated between working and training.

Cost asymmetry is also incorporated in our model. We consider that firm-financed training does not imply either monetary or time opportunity costs from the employee's perspective, publicfinanced training involves a time opportunity cost, and training fully financed by the employee entails both monetary and time opportunity costs. It is worth pointing out that, since each training type is linked to different wage returns and different costs of training, this differentiation plays a significant role in the employee decision to train, or not. The budget constraint takes the following form: 


$$
c+p_{s} t_{s} \leq\left(1-t_{p}-t_{s}\right) w^{i}\left(t_{f}, t_{p}, t_{s}\right), \quad i=\text { male, female, }
$$

where $w^{i}$ is the wage rate that allows for different returns to training in terms of gender and $p_{s}$ is the price the employee pays for a course without firm or public financing.

Although this model is static, dynamic issues can be introduced by considering $w^{i}$ as the present value of the wage stream during the working life. Those who tend to have shorter working lives will expect lower returns from any type of training and more substantial economic obstacles in accessing self-financed training.

It is logical to consider that the variables $t_{f}$ and $t_{p}$ are bounded by the amount of training supplied by the firm $\left(T_{f}^{i}\right)$ and by the public sector $\left(T_{p}\right)$. According to the Taste and Statistical Discrimination Theory of Correll et al. (2007), the training participation gap between males and females could be a consequence of employer discriminatory practices. Statistical discrimination occurs when employers believe that women have a weaker attachment to the job than men and, therefore, to invest in training for women (which implies direct training costs and/or indirect costs for production) is not worth it from the employer's perspective. Taste discrimination does not rely on economic motivation; it is exclusively based on the cultural stereotypes held by the employer. Whatever the source of gender discrimination, it provokes a shortage of firm-financed training supply among women. Taking $T_{f}^{i}$ as the upper bound of firm-financed training, it is feasible to interconnect the rationale of the worker and the employer regarding training. Gender discrimination or occupational gender segregation would easily be represented in this framework by establishing the $T_{f}^{\text {female }}<T_{f}^{\text {male }}$ condition.

Taking previous considerations into account, each individual (male or female) faces the following problem:

$$
\begin{gathered}
\operatorname{Max}_{c, t_{f}, t_{p}, t_{s}} \quad U^{i}=V(c)+Z^{i}\left(t_{f}, t_{p}, t_{s}\right)-\Phi^{i}\left(t_{f}, t_{p}, t_{s}\right) \quad i=\text { male, female, } \\
\text { Subject to } c+p_{s} t_{s} \leq\left(1-t_{p}-t_{s}\right) w^{i}\left(t_{f}, t_{p}, t_{s}\right) \\
0 \leq t_{f} \leq T_{f}^{i} \\
0 \leq t_{p} \leq T_{f} \\
t_{p}+t_{s}<1
\end{gathered}
$$




$$
c>0, \quad t_{s} \geq 0
$$

The interior solution for each type of training, e. g. $0<t_{f}<T_{f}^{i}, 0<t_{p}<T_{p}$ and $0<t_{s}<1$, meets the following necessary conditions, respectively (the problem is solved in Appendix A).:

$$
\begin{aligned}
& Z_{t_{f}}^{i}+V^{\prime}\left(1-t_{p}-t_{s}\right) w_{t_{f}}^{i}=\Phi_{t_{f}}^{i} \\
& Z_{t_{p}}^{i}+V^{\prime}\left(1-t_{p}-t_{s}\right) w_{t_{p}}^{i}=\Phi_{t_{p}}^{i}+V^{\prime} w^{i}\left(t_{f}, t_{p}, t_{s}\right) \\
& Z_{t_{s}}^{i}+V^{\prime}\left(1-t_{p}-t_{s}\right) w_{t_{s}}^{i}=\Phi_{t_{s}}^{i}+V^{\prime} w^{i}\left(t_{f}, t_{p}, t_{s}\right)+V^{\prime} p_{t_{s}}
\end{aligned}
$$

The above expressions establish that an individual decides to increase (decrease) their participation in each training type if the sum of returns derived from this training exceeds (is less than) the sum of marginal costs. Obviously, if each training type generates similar net returns in terms of utility, those employees who decide to train will choose firm-financed training because of the expected higher wage return and the lack of economic cost. However, it is plausible to think that a firm-training supply restriction may be binding, such that equation (3) will become invalid. If the supply of training by the employer is insufficient to cover employee demands, those individuals with a greater demand for training will turn to public-financed training, implying a cost in terms of time. If the public supply of training is unable to meet the demand, individuals will decide to selffinance their training, incurring both time and monetary costs. Thus, if access to firm-provided training is more limited for women than for men, women will turn to public-financed training and/or self-financed training. In any case, if each training type leads to different benefits and costs in terms of utility, multiple scenarios could arise. The empirical evidence will help us to identify a plausible scenario for the Spanish case.

\section{Data description and empirical results}

For the empirical analysis of this paper we have used survey data that includes detailed information on the incidence of training among Spanish workers. The survey was conducted in 2007 in three Spanish cities, with a sample of 2,833 workers. To ensure that the sample is representative, the distribution of worker characteristics is in line with their relative importance with respect to the Active Population Survey ${ }^{2}$ regarding gender, age, employment status, and economic occupation. From the original sample, self-employed and unemployed persons are excluded,

\footnotetext{
${ }^{2}$ Active Population Survey is a national representative longitudinal survey provided by the Spanish Statistical Office (INE), whose main objective is to compile data on the Spanish labor force.
} 
reducing the original sample to 2,170 observations, 1,041 males (47.9\%) and 1,129 females (52.1\%).

The data includes a large set of demographic and socio-economic characteristics, educational background, job attributes, and firm characteristics. The survey also includes detailed information regarding respondent training activities. Training is defined as participation in professionallyoriented courses during the prior two years. Individuals were asked whether training expenditures were incurred and whether financial support came from their employer or from public institutions. They were also asked whether the course was held, or not, during working hours. Following the classification given in the theoretical framework, that is in line with the categorization proposed by Lerman et. al (2004), who define employer provided training as "all apprenticeships, and any type of training for which an employer provided instruction, gave time off from work with or without pay, provided classroom space, or paid all or part of the cost", we classify individual continuous training into three different categories: (1) Firm-financed training, including all courses that are either monetary- or time-financed by the firm (2) public-financed courses, courses financed by public programs and taking place outside working hours; and (3) self-financed courses, any training paid for by the employee, outside working hours.

To further explore the motivations to attend a course, and the returns from the training, to those who answered affirmatively the question on training, the survey provides information about the following: (1) This training is appropriate to the job (2) This training can be used for advancement at the work place (3) It is useful for professional career (4) It has been recommended by the employer (5) Attendance is obligatory (6) It can increase the chances of finding another job.

Respondents were also asked whether or not they obtained any of the following benefits from training: (7) I have learned what I was expecting to learn, (8) I have been promoted at the firm, (9) I have been able to find a better job, (10) It has increased my wages/salary. For each of these questions, respondents respond with a value on a scale of 1 (completely disagree) to 5 (completely agree).

In Table 1, descriptive statistics regarding training activities are reported for women and men, showing sample means of training participation in different types of course, separated by gender. Overall training participation in any course during the prior two years is slightly higher among men (60.2\%) than women (58.1\%), although the difference is not statistically significant. However, if different categories of training are considered, female average participation rates in self-financed or public-financed courses are significantly higher than those of males, whereas men participate 
significantly more often in firm-financed courses. While $44 \%$ of males participate in courses financed by the employer, or held during working hours, this ratio is only $35 \%$ for women. The differences intensify when we only consider workers who have received training (lower part of the table). The male-female gap in firm-provided training is almost 13 points, while women tend to participate in other types of training.

Table 1: Gender differences in training characteristics

\begin{tabular}{|c|c|c|c|c|c|c|c|c|}
\hline & \multicolumn{2}{|c|}{ Pooled } & \multicolumn{2}{|c|}{ Male } & \multicolumn{2}{|c|}{ Female } & \multirow[b]{2}{*}{ Diff } & \multirow[b]{2}{*}{ t-ratio } \\
\hline & $\mathbf{N}$ & $\%$ & $\mathbf{N}$ & $\%$ & $\mathbf{N}$ & $\%$ & & \\
\hline \multicolumn{9}{|l|}{ Total sample: 2170 workers } \\
\hline Any type of training & 1285 & $59.2 \%$ & 627 & $60.2 \%$ & 656 & $58.1 \%$ & $2.1 \%$ & 1.01 \\
\hline Firm-financed training & 859 & $39.5 \%$ & 460 & $44.2 \%$ & 375 & $35.2 \%$ & $9.0 \% * * *$ & 4.31 \\
\hline Public-financed training & 346 & $15.9 \%$ & 142 & $13.6 \%$ & 204 & $18.1 \%$ & $-4.4 \% * * *$ & -2.82 \\
\hline Self-financed training & 70 & $3.2 \%$ & 21 & $2.0 \%$ & 49 & $4.3 \%$ & $-2.3 \% * * *$ & -3.06 \\
\hline \multicolumn{9}{|c|}{ Sub-sample of trained workers: 1285 workers } \\
\hline Firm-provided training & 859 & $67.4 \%$ & 460 & $73.8 \%$ & 375 & $61.1 \%$ & $12.8 \% * * *$ & 4.89 \\
\hline Public-financed training & 346 & $27.1 \%$ & 142 & $22.8 \%$ & 204 & $31.4 \%$ & $-8.6 \% * * *$ & -3.46 \\
\hline Self-financed training & 70 & $5.5 \%$ & 21 & $3.4 \%$ & 49 & $7.5 \%$ & $-4.2 \% * * *$ & -3.27 \\
\hline
\end{tabular}

In the empirical framework, we run probit regression models to predict worker training participation in the pooled sample of male and female workers. Additionally, we estimate genderspecific models of training participation. Let $T$ be the unobserved benefits of receiving any kind of training. These benefits are associated with individual personal characteristics, together with job and firm characteristics. A specific worker will be participating in continuous training as long as $T$ is greater than zero. In practice, $T$ is unobserved, and is replaced in the estimated models by its binary counterpart $C$, which takes a value of 1 if the worker participates in any type of training and 0 otherwise. Since $X$ is a vector of personal and job characteristics, and $\mu$ the error term, the decision may be modeled as a latent variable model in which the net benefit of training for the employees is given by:

$$
\left\{\begin{array}{l}
T=\beta X+\mu, \\
C=1 \text { if Training }>0 \\
C=0 \text { if Training } \leq 0
\end{array}\right.
$$

Specifically, the estimations are based on the following model:

$$
\operatorname{Pr} o b(C)=\alpha_{0}+\sum_{i} \alpha_{i} X_{i}+\mu
$$

Following Simpson and Stroh (2002), the variables included in $X$ are personal characteristics such as gender, age, nationality, and educational level, together with other job-related attributes 
such as job position, firm tenure, firm size, economic sector, and enterprise ownership. We run our models on a pooled sample of male and female workers, and then estimate gender-specific models of training participation in an attempt to unravel which personal and firm characteristics most strongly influence the probability that an employee participates in training. A detailed description of these variables can be found in Appendix B.

The models of training participation are displayed in Table 2. With respect to personal characteristics, the most important finding is that gender has no significant effect on the probability of training, meaning that, overall, workers in Spain train in the same way, at the same rates, regardless of gender. Focusing on the gender-specific models, female training investments seem to take place at a greater rate for the group aged between 45 and 54 . For males, the probability of training increases between age 40 and 44, although in the gender-specific models, this effect only appears for female workers, not for males.

We find a positive association between acquired formal education and subsequent training in our pooled regression, but only in the case of women for the individual probits. The underlying rationale is that the incidence of training increases with education, since training and education are complementary. Arulampalam, et al, 2004 find that this complementarity holds for both men and women.

With respect to job and firm characteristics, we find that larger firms are much more likely to provide their employees with training than smaller companies. Asplund (2005) explains that smaller firms can be more concerned about trained employees being hired away by competitors, and may also be more financially-constrained. Moreover, large firms pay higher wages and, hence, have lower employee turnover (Holzer and Reaser, 1999; Leuven and Oosterbeck, 1999). Also, the results seem to reflect the conventional view that employers are less likely to provide training for those with shorter tenure due to the risk of labor market turnover - but only for men, not for women. Substantial differences in the provision of training are also evident across single economic sectors. Industry, service, and agriculture workers train less than those in construction. Finally, women are more likely to receive training if they are employed in the public sector. 
Table 2: Determinants of receiving any type of training

\begin{tabular}{|c|c|c|c|c|c|c|}
\hline & \multicolumn{2}{|c|}{ Pooled } & \multicolumn{2}{|c|}{ Men } & \multicolumn{2}{|c|}{ Women } \\
\hline & Coeff. & $\begin{array}{l}\text { Marg. } \\
\text { effect }\end{array}$ & Coeff. & $\begin{array}{l}\text { Marg. } \\
\text { effect }\end{array}$ & Coeff. & $\begin{array}{r}\text { Marg. } \\
\text { effect }\end{array}$ \\
\hline \multicolumn{7}{|l|}{ Personal characteristics } \\
\hline Female & -0.04 & -0.016 & & & & \\
\hline Age: 25 to 29 & 0.16 & 0.062 & 0.17 & 0.062 & 0.14 & 0.052 \\
\hline Age: 30 to 39 & 0.00 & -0.001 & 0.06 & 0.024 & -0.09 & -0.035 \\
\hline Age: 40 to 44 & $0.33 * * *$ & $0.122 * * *$ & $0.42 * *$ & $0.152 * *$ & 0.27 & 0.100 \\
\hline Age: 45 to 54 & $0.26 * *$ & $0.096 * *$ & 0.24 & 0.090 & $0.29 *$ & $0.108 *$ \\
\hline Age: more than 54 & -0.05 & -0.018 & -0.05 & -0.017 & -0.03 & -0.012 \\
\hline Foreign & $-0.32 * *$ & $-0.126 * *$ & -0.14 & -0.054 & $-0.49 * *$ & $-0.194 * *$ \\
\hline Secondary education & $0.18 * *$ & $0.069 * *$ & 0.12 & 0.047 & $0.24 *$ & $0.093 *$ \\
\hline College education & $0.36 * * *$ & $0.135 * * *$ & 0.21 & 0.079 & $0.46 * * *$ & $0.176 * * *$ \\
\hline \multicolumn{7}{|l|}{ Job and firm characteristics } \\
\hline Category: Administrative Support & 0.08 & 0.032 & -0.06 & -0.023 & 0.20 & 0.076 \\
\hline Category: Clerk & -0.12 & -0.048 & -0.13 & -0.050 & -0.13 & -0.052 \\
\hline $\begin{array}{l}\text { Category: Senior/mid level } \\
\text { official }\end{array}$ & -0.16 & -0.060 & -0.22 & -0.083 & -0.10 & -0.038 \\
\hline Category: Low skill official & $-0.26 *$ & $-0.102 *$ & -0.21 & -0.080 & -0.37 & -0.146 \\
\hline Category: Unskilled worker & -0.19 & -0.073 & -0.11 & -0.042 & -0.24 & -0.095 \\
\hline Area: Management & 0.10 & 0.038 & 0.04 & 0.014 & 0.28 & 0.102 \\
\hline Area: Administration & 0.08 & 0.030 & 0.07 & 0.025 & 0.07 & 0.028 \\
\hline Area: Marketing & $-0.20 * *$ & $-0.079 * *$ & -0.05 & -0.019 & $-0.25 * *$ & $-0.097 * *$ \\
\hline Area: Production & $-0.16 *$ & $-0.063 *$ & $-0.25 * *$ & $-0.098 * *$ & -0.06 & -0.023 \\
\hline Tenure: 1 to 3 years & $0.26 * * *$ & $0.096 * * *$ & 0.21 & 0.080 & $0.31 * *$ & $0.117 * *$ \\
\hline Tenure: 3 to 5 years & 0.10 & 0.039 & 0.21 & 0.077 & 0.06 & 0.023 \\
\hline Tenure: more than 5 years & $0.20 * *$ & $0.076 * *$ & $0.35 * *$ & $0.135 * *$ & 0.06 & 0.022 \\
\hline Size: 10 to 50 workers & $0.32 * * *$ & $0.120 * * *$ & $0.48 * * *$ & $0.174 * * *$ & $0.27 * *$ & $0.101 * *$ \\
\hline Size: 51 to 200 workers & $0.53 * * *$ & $0.188 * * *$ & $0.76 * * *$ & $0.258 * * *$ & $0.36 * *$ & $0.133 * *$ \\
\hline Size: 201 to 500 workers & $0.53 * * *$ & $0.187 * * *$ & $0.79 * * *$ & $0.259 * * *$ & $0.37 * *$ & $0.134 * *$ \\
\hline Size: More than 500 workers & $0.55 * * *$ & $0.207^{* * *}$ & $0.83 * * *$ & $0.300 * * *$ & $0.41 * * *$ & $0.155 * * *$ \\
\hline Sector: service & $-0.51 * * *$ & $-0.191 * * *$ & $-0.45 * * *$ & $-0.173 * * *$ & $-0.62 * * *$ & $-0.222 * * *$ \\
\hline Sector: industry & $-0.52 * * *$ & $-0.203 * * *$ & $-0.57 * * *$ & $-0.220 * * *$ & $-0.51 * *$ & $-0.201 * *$ \\
\hline Sector: agriculture & $-0.48 *$ & $-0.190 *$ & -0.36 & -0.141 & -0.63 & -0.246 \\
\hline Public ownership & $0.21 * *$ & $0.081 * *$ & 0.02 & 0.007 & $0.33 * * *$ & $0.124 * * *$ \\
\hline Constant & -0.03 & & -0.22 & & 0.09 & \\
\hline $\mathrm{N}^{\circ}$ of Observations & 2043 & & 986 & & 1057 & \\
\hline Pseudo $\mathrm{R}^{2}$ & $10 \%$ & & $9 \%$ & & $12 \%$ & \\
\hline
\end{tabular}

*** $\mathrm{p}<0,01, * * \mathrm{p}<0,05, * \mathrm{p}<0,1$

Overall, there is no gender gap in the probability of training, but we wonder whether differentials may appear in different types of training. The following step of our analysis focuses on those who have participated in training. In particular, we are interested in the probabilities and 
determinants of taking part in each of the three types of training: firm-financed training, publicfinanced training, and self-financed training. We use a multinomial regression analysis where we assume that the log-odds of each response follow a linear model. The multinomial logistic regression model is a simple extension of the binomial logistic regression model, used when the dependent variable has more than two nominal or unordered categories. Through the logistic transformation, each type of training is assigned log-odds, given its relation to the reference category. In particular, multinomial logistic regression is estimated for log-odds of receiving publicor self-financed training, versus firm- financed training as the reference category.

Table 3 shows that the distinction between firm-financed and the other types of training is relevant. The distinction between employer-provided and the other types of training yields important insights, since the indicator related to gender is positive and highly significant. Being female negatively affects the probability of participating in firm-financed training as compared to self-financed or public-financed training. In particular, and other things held constant, women are almost twice more likely than men to participate in public-financed training versus firm-financed training. For self-financed training, this probability is 1.56 points. Thus, the female workforce appears disadvantaged in access to employer-provided training, even if it has comparable human capital and works in similar firms, industries, and occupations. This finding is in line with other studies reporting negative effects for women on the probability of receiving employer-provided training (Bassani et al., 2007, Backes-Gellner et al., 2011).

Other variables that negatively affect the probability of participating in firm-financed training as compared to public-financed courses are, to be aged between 30 and 39, and to work in the service or industry sectors. On the other hand, working for a large firm and with longer tenures clearly increases the probability that an employee will take part in firm-financed training.

Focusing on self-financed training, those working in the service sector are more likely to finance their own training versus firm-financed training. To be aged between 40 and 54, and to have a contract longer than five years, slightly increases the probability of participating in firm-financed training. Also, holding other things constant, workers with higher education are five times more likely to pay for their own education than to participate in company- provided training. 
Table 3: Multinomial analysis: Determinants of participation in publicly-financed and selffinanced training versus firm-provided training

\begin{tabular}{|c|c|c|c|c|}
\hline & \multicolumn{2}{|c|}{$\begin{array}{l}\text { Public-financed versus firm- } \\
\text { financed training }\end{array}$} & \multicolumn{2}{|c|}{$\begin{array}{l}\text { Self-financed versus firm- } \\
\text { financed training }\end{array}$} \\
\hline & Coefficient & Odds ratio & Coefficient & Odds ratio \\
\hline \multicolumn{5}{|l|}{ Personal characteristics } \\
\hline Female & $0.61 * * *$ & 1.85 & $0.44 *$ & 1.56 \\
\hline Age: 25 to 29 & 0.17 & 1.18 & -0.14 & 0.87 \\
\hline Age: 30 to 39 & $0.61 * *$ & 1.84 & -0.38 & 0.69 \\
\hline Age: 40 to 44 & 0.43 & 1.54 & $-1.05 *$ & 0.35 \\
\hline Age: 45 to 54 & 0.35 & 1.43 & $-1.09 *$ & 0.34 \\
\hline Age: more than 54 & 0.47 & 1.60 & -1.81 & 0.16 \\
\hline Foreign & $-0.75 *$ & 0.47 & -0.81 & 0.44 \\
\hline Secondary education & $0.43 *$ & 1.54 & 1.22 & 3.38 \\
\hline College education & 0.08 & 1.08 & $1.69 * *$ & 5.44 \\
\hline \multicolumn{5}{|l|}{ Job and firm characteristics } \\
\hline Category: Administrative Support & -0.42 & 0.66 & -0.05 & 0.95 \\
\hline Category: Clerk & $-0.54 * *$ & 0.58 & -0.37 & 0.69 \\
\hline Category: Senior/mid level official & -0.38 & 0.68 & -0.88 & 0.42 \\
\hline Category: Low skill official & 0.46 & 1.58 & -0.25 & 0.78 \\
\hline Category: Unskilled worker & -0.39 & 0.68 & -0.01 & 0.99 \\
\hline Area: Management & -0.46 & 0.63 & -13.87 & 0.00 \\
\hline Area: Administration & -0.01 & 0.99 & -0.42 & 0.66 \\
\hline Area: Marketing & -0.37 & 0.69 & -0.10 & 0.91 \\
\hline Area: Production & 0.29 & 1.34 & 0.56 & 1.75 \\
\hline Tenure: 1 to 3 years & -0.12 & 0.88 & -0.35 & 0.70 \\
\hline Tenure: 3 to 5 years & -0.03 & 0.97 & -0.53 & 0.59 \\
\hline Tenure: more than 5 years & $-0.66 * * *$ & 0.52 & $-0.73 *$ & 0.48 \\
\hline Size: 10 to 50 workers & -0.18 & 0.84 & $-0.97 *$ & 0.38 \\
\hline Size: 51 to 200 workers & $-0.65 * *$ & 0.52 & -0.60 & 0.55 \\
\hline Size: 201 to 500 workers & $-0.52 *$ & 0.59 & $-1.34 *$ & 0.26 \\
\hline Size: More than 500 workers & $-0.99 * * *$ & 0.37 & -0.61 & 0.54 \\
\hline Sector: service & $0.54 * *$ & 1.72 & $1.44 * *$ & 4.24 \\
\hline Sector: industry & $0.71 * * *$ & 2.04 & 0.79 & 2.20 \\
\hline Sector: agriculture & 0.33 & 1.38 & 1.43 & 4.20 \\
\hline Public ownership & 0.29 & 1.34 & 0.36 & 1.44 \\
\hline Constant & $-1.23 * * *$ & & $-3.62 * * *$ & \\
\hline
\end{tabular}

Prob $>$ chi $^{2}=0.0$, Log likelihood $=-844.0281$, Pseudo $\mathrm{R}^{2}=9,5 \%$ $* * * \mathrm{p}<0,01,{ }^{* *} \mathrm{p}<0,05,{ }^{*} \mathrm{p}<0,1$

Our analysis shows that being female negatively affects the probability of participating in firm-financed training as compared to self-financed or public-financed courses. One explanation of why women attend more public- and self-financed training is that women to resort to publiclyfinanced training to compensate for gender discrimination. 
We go one step further in our analysis studying gender differences in motivation and the returns to each type of training by using mean differences in the respondent self-evaluation of the courses. One-way analysis of variance is used to extend the information by determining whether there are any significant differences between the means of the three types of courses; the Scheffe post-hoc procedure is used to compare differences between all pairs of means.

As revealed by Table 4, different types of training commonly have opposite effects on motivation and returns. It appears that training decisions are determined differently, compared to self-initiated courses. Training provided by firms is focused on developing the skills and competencies that employers consider more appropriate for the job. By giving financial support to their workers, firms play an important role in individual training decisions. On the other hand, employees have an incentive to participate in training since they can expect positive effects, not only on wages, but also on career development within the firm.

In line with other studies (Fitzenberger and Muehler, 2011), our results reveal that participation in employer-provided training has a positive impact on the wages of the trained employees. The problem is that training is not equally distributed to employees. Furthermore, since men and women are not equally likely to obtain training, employer-provided training stands out as a contributor to wage and earnings inequality. The results also show that unequal access to training for women leads to poorer promotion prospects, and therefore lower pay.

In the case of self-initiated courses, either financed by the employee or by a public institution, the employee bears all costs by paying for the training, or by spending their free time; thus, they should obtain some post-training returns from their investment. Workers who attend these types of courses go for training that is beneficial to their professional career, and/or courses that can potentially increase their chances of finding a better job. 
Table 4: Mean differences for the returns of different types of training (Scheffe Test).

\begin{tabular}{|c|c|c|c|c|}
\hline & $\begin{array}{l}\text { Type of } \\
\text { training (I) }\end{array}$ & $\begin{array}{l}\text { Type of } \\
\text { training }(\mathrm{J})\end{array}$ & $\begin{array}{l}\text { Mean Diff. } \\
\text { (I-J) }\end{array}$ & Sig. \\
\hline \multirow{2}{*}{ It is appropriate for my job } & Firm & $\begin{array}{l}\text { Self-financed } \\
\text { Public }\end{array}$ & $\begin{array}{l}0.13 \\
0.48 * * *\end{array}$ & $\begin{array}{l}0.68 \\
0.00\end{array}$ \\
\hline & Public & $\begin{array}{l}\text { Self-financed } \\
\text { Firm }\end{array}$ & $\begin{array}{l}-0.35 * \\
-0.48 * * *\end{array}$ & $\begin{array}{l}0.09 \\
0.00\end{array}$ \\
\hline \multirow{2}{*}{$\begin{array}{l}\text { Can be used for advancement at the } \\
\text { workplace }\end{array}$} & Firm & $\begin{array}{l}\text { Self-financed } \\
\text { Public }\end{array}$ & $\begin{array}{l}0.18 \\
0.29 * * * \\
\end{array}$ & $\begin{array}{l}0.61 \\
0.01\end{array}$ \\
\hline & Public & $\begin{array}{l}\text { Self-financed } \\
\text { Firm }\end{array}$ & $\begin{array}{l}-0.11 \\
-0.29 * * *\end{array}$ & $\begin{array}{l}0.84 \\
0.01\end{array}$ \\
\hline \multirow{2}{*}{ Is useful for my career } & Firm & $\begin{array}{l}\text { Self-financed } \\
\text { Public }\end{array}$ & $\begin{array}{l}-0.35 * \\
-0.10\end{array}$ & $\begin{array}{l}0.08 \\
0.47\end{array}$ \\
\hline & Public & $\begin{array}{l}\text { Self-financed } \\
\text { Firm }\end{array}$ & $\begin{array}{r}-0.25 \\
0.10 \\
\end{array}$ & $\begin{array}{l}0.31 \\
0.47\end{array}$ \\
\hline \multirow{2}{*}{ Has been suggested by the company } & Firm & $\begin{array}{l}\text { Self-financed } \\
\text { Public }\end{array}$ & $\begin{array}{l}1.48 * * * \\
1.32 * * *\end{array}$ & $\begin{array}{l}0.00 \\
0.00\end{array}$ \\
\hline & Public & $\begin{array}{l}\text { Self-financed } \\
\text { Firm }\end{array}$ & $\begin{array}{l}0.17 \\
-1.32 * * * \\
\end{array}$ & $\begin{array}{l}0.67 \\
0.00\end{array}$ \\
\hline \multirow{2}{*}{ Attendance is obligatory } & Firm & $\begin{array}{l}\text { Self-financed } \\
\text { Public }\end{array}$ & $\begin{array}{l}0.99 * * * \\
0.75 * * *\end{array}$ & $\begin{array}{l}0.00 \\
0.00\end{array}$ \\
\hline & Public & $\begin{array}{l}\text { Self-financed } \\
\text { Firm }\end{array}$ & $\begin{array}{l}0.24 \\
-0.75 * * *\end{array}$ & $\begin{array}{l}0.56 \\
0.00\end{array}$ \\
\hline \multirow{2}{*}{ Increases the chances of finding a job } & Firm & $\begin{array}{l}\text { Self-financed } \\
\text { Public }\end{array}$ & $\begin{array}{l}-0.43 * \\
-0.24 *\end{array}$ & $\begin{array}{l}0.09 \\
0.06\end{array}$ \\
\hline & Public & $\begin{array}{l}\text { Self-financed } \\
\text { Firm }\end{array}$ & $\begin{array}{l}-0.18 \\
0.24 *\end{array}$ & $\begin{array}{l}0.67 \\
0.06\end{array}$ \\
\hline \multirow{2}{*}{ I have learnt what I expected to learn } & Firm & $\begin{array}{l}\text { Self-financed } \\
\text { Public }\end{array}$ & $\begin{array}{r}0.02 \\
-0.13 \\
\end{array}$ & $\begin{array}{l}0.99 \\
0.22\end{array}$ \\
\hline & Public & $\begin{array}{l}\text { Self-financed } \\
\text { Firm }\end{array}$ & $\begin{array}{l}0.15 \\
0.13\end{array}$ & $\begin{array}{l}0.60 \\
0.22\end{array}$ \\
\hline \multirow{2}{*}{ I have been promoted at the firm } & Firm & $\begin{array}{l}\text { Self-financed } \\
\text { Public }\end{array}$ & $\begin{array}{l}0.33 \\
0.31^{\text {*** }}\end{array}$ & $\begin{array}{l}0.13 \\
0.00\end{array}$ \\
\hline & Public & $\begin{array}{l}\text { Self-financed } \\
\text { Firm }\end{array}$ & $\begin{array}{c}0.02 \\
-0.31 * * *\end{array}$ & $\begin{array}{l}0.99 \\
0.00\end{array}$ \\
\hline \multirow{2}{*}{ I have been able to find a better job } & Firm & $\begin{array}{l}\text { Self-financed } \\
\text { Public }\end{array}$ & $\begin{array}{l}0.01 \\
0.05\end{array}$ & $\begin{array}{l}1.00 \\
0.75\end{array}$ \\
\hline & Public & $\begin{array}{l}\text { Self-financed } \\
\text { Firm }\end{array}$ & $\begin{array}{l}-0.04 \\
-0.05 \\
\end{array}$ & $\begin{array}{l}0.95 \\
0.75 \\
\end{array}$ \\
\hline \multirow{2}{*}{ It has increased my wages } & Firm & $\begin{array}{l}\text { Self-financed } \\
\text { Public }\end{array}$ & $\begin{array}{l}0.11 \\
0.20 * *\end{array}$ & $\begin{array}{l}0.77 \\
0.04\end{array}$ \\
\hline & Public & $\begin{array}{l}\text { Self-financed } \\
\text { Firm }\end{array}$ & $\begin{array}{l}-0.09 \\
-0.20 * *\end{array}$ & $\begin{array}{l}0.85 \\
0.04\end{array}$ \\
\hline
\end{tabular}

Finally, Student's t-test compares the means for the two samples, male and female, for each type of training (table 5). Our findings suggest that, when it comes to courses that individuals mostly decide for themselves to participate in, the factors influencing the decision differ significantly between men and women, but there are no differences in the economic returns from 
those courses. Female workers attend public- or self-financed courses because they find this training appropriate for their job and useful for their career, to a greater extent than men.

Regarding firm-financed courses, however, there is a statistically significant difference in wages, in that men who attend training courses financially supported by their employers, report higher average increases in wages compared to women participating in the same type of training. These gender differentials in company training participation, and in greater wage increases for male trainees, have the potential to explain a significant portion of the gender-wage gap. Furthermore, since men and women are not equally likely to obtain training, firm-financed training stands out as a contributor to wage and earnings inequality.

Table 5: Gender differences on the returns from training

\begin{tabular}{|l|ccc|ccc|ccc|}
\hline & \multicolumn{3}{|c|}{ Firm financed } & \multicolumn{3}{c|}{ Public financed } & \multicolumn{3}{c|}{ Self financed } \\
& Men & Women & Diff & Men & Women & Diff & Men & Women & Diff \\
\cline { 2 - 9 } It is appropriate for my job & 3.87 & 3.96 & -0.1 & 3.18 & 3.61 & $-0.43^{* * *}$ & 3.35 & 3.96 & $-0.61^{*}$ \\
For advancement at the workplace & 2.98 & 3.09 & -0.11 & 2.71 & 2.77 & -0.06 & 2.65 & 2.94 & -0.29 \\
Is useful for my career & 3.62 & 3.66 & -0.05 & 3.50 & 3.90 & $-0.40^{* * *}$ & 3.55 & 4.16 & $-0.61^{* *}$ \\
Has been suggested by the company & 3.16 & 3.00 & 0.17 & 1.74 & 1.79 & -0.06 & 1.74 & 1.55 & 0.19 \\
Attendance is obligatory & 3.06 & 2.82 & $0.24^{* *}$ & 2.14 & 2.23 & -0.08 & 1.95 & 1.96 & -0.01 \\
Increases the chances of finding a job & 2.66 & 2.74 & -0.08 & 2.77 & 3.05 & $-0.29 *$ & 3.05 & 3.15 & -0.1 \\
I have learnt what I expected to learn & 3.53 & 3.58 & -0.05 & 3.64 & 3.71 & -0.07 & 3.71 & 3.45 & 0.27 \\
I have been promoted at the firm & 2.27 & 2.15 & 0.12 & 1.85 & 1.95 & -0.10 & 1.76 & 1.94 & -0.18 \\
I have been able to find a better job & 1.63 & 1.55 & 0.08 & 1.54 & 1.55 & -0.01 & 1.76 & 1.51 & 0.25 \\
It has increased my wages & 1.88 & 1.69 & $0.19 * *$ & 1.49 & 1.66 & -0.17 & 1.81 & 1.63 & 0.18 \\
\hline
\end{tabular}

\section{Conclusions}

This paper has aimed to answer three main questions related to gender differences in continuous training for Spanish workers, using survey data that includes detailed information about respondent training activities. The first research question is whether there is any gender difference in the probability of taking part in continuous training. The results show that overall training participation in professionally-oriented courses is slightly higher among men than women, but the difference is not statistically significant. This brings us to our second research question, whether there are differences in the probability of taking part in different categories of training. Undoubtedly, differences between males and females arise once the source of financing the courses is taken into account. We find that firm-financed training is clearly biased towards men, while women must rely on public- or self-financed training to compensate for this gender discrimination. 
Our third research question addresses gender differences in the economic and non-economic returns to participation in different types of training. The persistent gender-wage gap continues to generate significant interest from researchers in economics and sociology, as well as in popular media. The intuition of this paper suggests that part of the differentials in pay outcomes may be due to the fact that women have limited access to firm training, but that is not the whole story. It appears that men are more likely than women to gain employer-provided training and that this has a more positive impact on their promotion prospects. Furthermore, men who attend training courses financially supported by their employers report higher average increases in wages, compared to women participating in the same type of training. This represents a double discrimination for women: they have less access to company-provided training, and their rewards from such training when they do participate in it - are not the same as for their male co-workers.

It appears evident that policies solely based on increasing overall participation rates in further training will not be sufficient. What is important is to know whether men and women are treated differently by their employers. To address that, subsidies for company training should be combined with additional policy measures, to ensure that firms do not restrict training access for women, and to undertake that the economic returns are equal for all workers. 


\section{References:}

Arulampalam, Wiji, Alison L. Booth and Mark L. Bryan. 2004. Training in Europe. Journal of the European Economic Association 2: 346-60.

Asplund, Rita. 2005. The Provision and Effects of Company Training: A Brief Review of the Literature. Nordic Journal of Political Economy 31: 47-73.

Backes-Gellner, Uschi, Yvonne Oswald and Simone N. Tuor. 2011. Part-time work and employer provided training: boon to women and bane to men? Working Paper no. 58, the Swiss Leading House on Economics and Education, Firm Behavior and Training Policies.

Becker, Gary. S. 1985. Human capital, effort, and the sexual division of labor. Journal of Labor Economics 3, no. 1: 33-58.

Correll, Shelley J., Stephen Benard and In Paik. 2007. Getting a job: is there a motherhood penalty? American Journal of Sociology 112, no. 5: 1297-338.

Dearden, Lorraine, Howard Reed and John Van Reenen. 2006. The Impact of Training on Productivity and Wages: Evidence from British Panel Data. Oxford Bulletin of Economics and Statistics 68, no. 4: 397-421.

Dieckhoff, Martina. and Steiber, Nadia. 2011. A Re-assessment of Common Theoretical Approaches to Explain Gender Differences in Continuing Training Participation. British Journal of Industrial Relations 49, no. 1: s135-s157.

England, Paula. 2005. Gender inequality in labor markets: The role of motherhood and segregation. Social Politics 12, no. 2: 264-288.

Evertsson, Marie. 2004. Formal on-the-job training: a gender-typed experience and wage-related advantage?’ European Sociological Review 20, no. 1: 79-93.

Fitzenberger, Bernd and Grit Muheler. 2011. Dips and Floors in workplace training: using personnel records to estimate gender differences. ZEW Discussion Papers 11-023.

Görlitz, Katja. 2011. Continuous training and wages. An empirical analysis using a comparison group approach. Economics of Education Review 30, no. 4: 691-701.

Havet, Nathalie and Guy Lacroix. 2010. La formation continue, un moyen de réduire les inégalités salariales entre hommes et femmes? Cahiers de recherche 1006, CIRPEE.

Havet, Nathalie and Catherine Sofer. 2008. Why do women's wages increase so slowly throughout their career? A dynamic model of statistical discrimination. Labour 22, no. 2: 291-314. 
Holzer, Harry and Jess Reaser. 1999. Firm-Level Training for Newly Hired Workers: Its Determinants and Effects. Research in Labor Economics 18: 377-402.

Jones, Melanie K., Latreille, Paul L. and Sloane, Peter J. 2008. Crossing the tracks? Trends in the training of male and female workers in Great Britain. British Journal of Industrial Relations 46, no. 2: 268-82.

Leuven, Edwin and Hessel Oosterbeek. 1999. The Demand and Supply of Work-Related Training. Research in Labor Economics 18: 303-330.

Leuven, Edwin and Hessel Oosterbeek. 2008. An alternative approach to estimate the wage returns to work-related training. Journal of Applied Econometrics 23: 423-434.

Lerman, Robert I., Signe-Mary McKernan and Stephanie Riegg. 2004. The Scope of EmployerProvided Training in the United States: Who, What, Where, and How Much?" In Job Training Policy in the United States, ed. Christopher J. O'Leary, Robert A. Straits and Stephen A. Wagner, Kalamazoo, MI: W.E. Upjohn Institute, 211-244.

Simpson, Patricia A. and Linda K. Stroh, 2002. Revisiting gender variation in training. Feminist Economics 8, no. 3: 21-53.

Siebern-Thomas, Frank. 2005. Job quality in European labour markets, in Job Quality and Employer Behaviour, ed. Stephen Bazen, Claudio Lucifora and Wiemer Salverda, Palgrave Macmillan, Basingstoke, Hants, 31-66.

Takayama, Akira. 1993. Analytical Methods in Economics. University of Michigan Press.

Tomaskovic-Devey, Donald and Sheryl Skaggs. 2002 Gender Segregation, Labor Process Organization and Gender Earnings Inequality. American Journal of Sociology 108:102-128 


\section{Appendix A:}

The Lagrangian has the following expression:

$$
\begin{aligned}
L^{i} & =V(c)+Z^{i}\left(t_{f}, t_{p}, t_{s}\right)-\Phi^{i}\left(t_{f}, t_{p}, t_{s}\right)+\lambda_{1}\left[\left(1-t_{p}-t_{s}\right) w^{i}\left(t_{f}, t_{p}, t_{s}\right)-c-p_{s} t_{s}\right]+\quad i=\text { male, female, } \\
& \lambda_{2}\left(T_{f}^{i}-t_{f}\right)+\lambda_{3}\left(T_{p}-t_{p}\right)
\end{aligned}
$$

with $\lambda_{1}, \lambda_{2}$ and $\lambda_{3}$ being Lagrange multipliers. The first-order conditions are the following:

$$
\begin{aligned}
& \frac{\partial L^{i}}{\partial c}=V^{\prime}-\lambda_{1}=0(1) \\
& \frac{\partial L^{i}}{\partial t_{f}}=Z_{t_{f}}^{i}-\Phi_{t_{f}}^{i}+\lambda_{1}\left(1-t_{p}-t_{s}\right) w_{t_{f}}^{i}-\lambda_{2} \leq 0(2) \\
& \frac{\partial L^{i}}{\partial t_{p}}=Z_{t_{p}}^{i}-\Phi_{t_{p}}^{i}+\lambda_{1}\left(1-t_{p}-t_{s}\right) w_{t_{p}}^{i}-\lambda_{1} w^{i}\left(t_{f}, t_{p}, t_{s}\right)-\lambda_{3} \leq 0(3) \\
& \frac{\partial L^{i}}{\partial t_{s}}=Z_{t_{s}}^{i}-\Phi_{t_{s}}^{i}+\lambda_{1}\left(1-t_{p}-t_{s}\right) w_{t_{s}}^{i}-\lambda_{1} w^{i}\left(t_{f}, t_{p}, t_{s}\right)-\lambda_{1} p_{t_{s}} \leq 0(4) \\
& T_{f}^{i}-t_{f} \geq 0(5) \\
& T_{p}-t_{p} \geq 0(6) \\
& \lambda_{2}\left(T_{f}^{i}-t_{f}\right)=0(7) \\
& \lambda_{3}\left(T_{p}-t_{p}\right)=0(8) \\
& \left(1-t_{p}-t_{s}\right) w^{i}\left(t_{f}, t_{p}, t_{s}\right)-c-p_{s} t_{s}=0(9)
\end{aligned}
$$

Assuming $U^{i}=V(c)+Z^{i}\left(t_{f}, t_{p}, t_{s}\right)-\Phi^{i}\left(t_{f}, t_{p}, t_{s}\right)$ is strictly quasi-concave, the first order conditions are necessary and sufficient (Takayama, 1993).

If we do not allow the possibility of corner solutions, conditions (7) and (8) lead to $\lambda_{2}=\lambda_{3}=0$ and conditions (2), (3) and (4) lead to:

$$
\begin{aligned}
& Z_{t_{f}}^{i}+V^{\prime}\left(1-t_{p}-t_{s}\right) w_{t_{f}}^{i}=\Phi_{t_{f}}^{i} \\
& Z_{t_{p}}^{i}+V^{\prime}\left(1-t_{p}-t_{s}\right) w_{t_{p}}^{i}=\Phi_{t_{p}}^{i}+V^{\prime} w^{i}\left(t_{f}, t_{p}, t_{s}\right) \\
& Z_{t_{s}}^{i}+V^{\prime}\left(1-t_{p}-t_{s}\right) w_{t_{s}}^{i}=\Phi_{t_{s}}^{i}+V^{\prime} w^{i}\left(t_{f}, t_{p}, t_{s}\right)+V^{\prime} p_{t_{s}}
\end{aligned}
$$




\begin{tabular}{|c|c|c|c|}
\hline & Pooled & Men & Women \\
\hline \multicolumn{4}{|c|}{ Dummy variables for the age of the respondent } \\
\hline Age: Les than 25 (reference) & 0.143 & 0.121 & 0.163 \\
\hline Age: 25 to 29 & 0.196 & 0.19 & 0.202 \\
\hline Age: 30 to 39 & 0.275 & 0.272 & 0.278 \\
\hline Age: 40 to 44 & 0.143 & 0.149 & 0.138 \\
\hline Age: 45 to 54 & 0.18 & 0.186 & 0.173 \\
\hline Age: more than 54 & 0.063 & 0.082 & 0.046 \\
\hline \multicolumn{4}{|c|}{ Dummy variable for the nationality of the respondent } \\
\hline Foreign & 0.058 & 0.066 & 0.051 \\
\hline \multicolumn{4}{|c|}{ Dummy variables for the level of formal education of the respondent: } \\
\hline Primary education (reference) & 0.191 & 0.228 & 0.156 \\
\hline Secondary education & 0.446 & 0.483 & 0.412 \\
\hline College education & 0.363 & 0.289 & 0.432 \\
\hline \multicolumn{4}{|c|}{ Dummy variables for Job category of the respondent: } \\
\hline Category: Qualified worker (reference) & 0.198 & 0.187 & 0.209 \\
\hline Category: Administrative Support & 0.13 & 0.119 & 0.14 \\
\hline Category: Clerk & 0.223 & 0.137 & 0.302 \\
\hline Category: Senior/mid level official & 0.244 & 0.303 & 0.189 \\
\hline Category: Low skill official & 0.083 & 0.126 & 0.044 \\
\hline Category: Unskilled worker & 0.122 & 0.127 & 0.116 \\
\hline \multicolumn{4}{|c|}{ Dummy variables for the area of work within the firm: } \\
\hline Area: Other areas (reference) & 0.385 & 0.4 & 0.371 \\
\hline Area: Management & 0.033 & 0.039 & 0.028 \\
\hline Area: Administration & 0.162 & 0.097 & 0.223 \\
\hline Area: Marketing & 0.184 & 0.106 & 0.255 \\
\hline Area: Production & 0.236 & 0.358 & 0.124 \\
\hline \multicolumn{4}{|c|}{ Dummy variables for the time worked at the firm (tenure) } \\
\hline Tenure: Less than 1 year (reference) & 0.237 & 0.199 & 0.272 \\
\hline Tenure: 1 to 3 years & 0.208 & 0.2 & 0.216 \\
\hline Tenure: 3 to 5 years & 0.109 & 0.098 & 0.118 \\
\hline Tenure: more than 5 years & 0.446 & 0.503 & 0.393 \\
\hline \multicolumn{4}{|c|}{ Dummy variables for the number of workers within the firm (size) } \\
\hline Less than 10 workers (reference) & 0.178 & 0.125 & 0.227 \\
\hline Size: 10 to 50 workers & 0.218 & 0.265 & 0.175 \\
\hline Size: 51 to 200 workers & 0.142 & 0.153 & 0.132 \\
\hline Size: 201 to 500 workers & 0.088 & 0.095 & 0.082 \\
\hline Size: More than 500 workers & 0.374 & 0.362 & 0.384 \\
\hline \multicolumn{4}{|c|}{ Dummy variables operating the sector of the firm (sector) } \\
\hline Sector: construction (reference) & 0.117 & 0.176 & 0.062 \\
\hline Sector: service & 0.652 & 0.46 & 0.83 \\
\hline Sector: industry & 0.216 & 0.348 & 0.095 \\
\hline Sector: agriculture & 0.015 & 0.016 & 0.013 \\
\hline \multicolumn{4}{|c|}{ Dummy variable for public or private ownership } \\
\hline Public ownership & 0.254 & 0.195 & 0.308 \\
\hline
\end{tabular}

